\title{
Xenopus embryos contain a somite-specific, MyoD-like protein that binds to a promoter site required for muscle actin expression
}

\author{
Michael V. Taylor, John B. Gurdon, Nicholas D. Hopwood, Norma Towers, ${ }^{1}$ \\ and Timothy J. Mohun ${ }^{1}$ \\ Wellcome/Cancer Research Campaign Institute and Department of Zoology, University of Cambridge, Cambridge, CB2 \\ 1QR, UK; ${ }^{1}$ National Institute for Medical Research, The Ridgeway, London, NW7 1AA, UK
}

\begin{abstract}
We identify the "M region" of the muscle-specific Xenopus cardiac actin gene promoter from -282 to -348 as necessary for the embryonic expression of a cardiac actin- $\beta$-globin reporter gene injected into fertilized eggs. Four DNA-binding activities in embryo extracts, embryonic M-region factors 1-4 (EMF1-4), are described that interact specifically with this region. One of these, EMF1, is detected in extracts from microdissected somites, which differentiate into muscle, but not in extracts from the adjacent neurectoderm, which differentiates into a variety of other cell types. Moreover, EMF1 is detected in embryo animal caps induced to form mesoderm, which includes muscle, and in which the cardiac actin gene is activated, but not in uninduced animal caps. EMF1 is also first detectable when cardiac actin transcripts begin to accumulate; therefore, both its temporal and spatial distributions during Xenopus development are consistent with a role in activating cardiac actin expression. Two lines of evidence suggest that EMF1 contains the myogenic factor Xenopus MyoD (XMyoD): (1) XMyoD synthesized in vitro can bind specifically to the same site as EMF1; and (2) antibodies raised against XMyoD bind to EMF1. DNA-binding studies indicate that EMF1 may be a complex between XMyoD and proteins found in muscle and other tissues. Our results suggest that the myogenic factor XMyoD, as a component of somite EMF1, regulates the activation of the cardiac actin gene in developing embryonic muscle by binding directly to a necessary region of the promoter.
\end{abstract}

[Key Words: MyoD; cardiac actin expression; myogenesis; Xenopus embryos; somites]

Received January 21, 1991; revised version accepted April 25, 1991.

In vertebrates, the cardiac actin gene is coexpressed with the skeletal actin gene in both the developing somites and the heart of the early embryo (Minty et al. 1982; Mohun et al. 1984; Sassoon et al. 1988). The focus of this study is cardiac actin expression in the somites. Musclespecific expression requires only several hundred base pairs of the cardiac actin gene promoter (Minty and Kedes 1986; Mohun et al. 1986; Quitschke et al. 1989). One approach to defining the regulatory promoter sequences within this region and to identifying the transcription factors that interact with them has been to use cultured myogenic cell lines as a model for muscle differentiation. However, several investigators have noted anomalies in the patterns of gene expression shown by such established cell lines (e.g., Muscat and Kedes 1987; Vaidya et al. 1989; Braun et al. 1990|, and it is uncertain how far these lines reflect the events of normal myogenesis.

An alternative approach is a direct analysis of gene activity in normal developing muscle during embryogenesis. In the frog, Xenopus laevis, expression of the cardiac actin gene is first detectable during gastrulation and is limited to that part of the newly formed mesoderm that gives rise to the somites (Mohun et al. 1984; Cascio and Gurdon 1986; Hopwood et al. 1989a). Its expression is maintained during the formation of the somites, which develop into the skeletal musculature. Cloned cardiac actin promoter-reporter gene constructs microinjected into fertilized eggs are expressed in a similarly restricted manner (Mohun et al. 1986; Wilson et al. 1986), which provides a direct assay to identify the promoter regions responsible for the embryonic activation of the cardiac actin gene.

Like all vertebrate muscle actin promoters (Minty and Kedes 1986; Mohun et al. 1986, 1989), the Xenopus cardiac actin promoter contains multiple copies of the 10 bp CArG box motif, CC(A/T) ${ }_{6}$ GG. Mutational analysis revealed that the most proximal of the four CArG boxes, CArG box 1, which is centered at -85 (Fig. 1A), is required for promoter activity in the frog embryo (Mohun et al. 1989|. CArG box1 binds the ubiquitous transcription factor, serum response factor (SRF) (Taylor et al. 1989; Mohun et al. 1991), and at least three other Xenopus embryo proteins (Taylor 1991). Although the CArG 
box, as well as its flanking sequences, is sufficient for muscle-specific expression of the chicken skeletal actin gene in primary cell cultures (Walsh 1989), it is neither sufficient for high-level expression directed by the human cardiac actin promoter in myogenic cell lines (Minty and Kedes 1986; Sartorelli et al. 1990), nor sufficient for activation of the Xenopus cardiac actin gene in frog embryos (Mohun et al. 1986, 1989).

In previous studies we found that an internal deletion of the Xenopus cardiac actin promoter that left CArG boxl intact, but that removed the other three CArG boxes positioned between -104 and -224 , had no inhibitory effect on the level or specificity of reporter gene expression in embryos. However, truncation of the promoter from -417 to -218 abolished transcription, indicating that sequences within this distal region were necessary for embryonic expression (Mohun et al. 1986, 1989).

In this paper we localize an essential distal sequence to a region from -282 to -348 in the cardiac actin gene promoter and show that it can bind the frog homolog of the mouse myogenic factor MyoD (Davis et al. 1987; Hopwood et al. 1989b; Harvey 1990; Scales et al. 1990). We describe four sequence-specific DNA-binding activities in the normal developing embryo that interact with this promoter region. One of these is first detected during early neurulation and is detectable in extracts from somites but not from nonmuscle tissues. It also contains Xenopus MyoD (XMyoD) or a related protein. The $\mathrm{XMyoD}$ gene is expressed in the somitic mesoderm before the activation of the cardiac actin gene (Hopwood et al. 1989b; Harvey 1990; Scales et al. 1990), and our data suggest a simple model in which $\mathrm{XMyoD}$ regulates the activation of the cardiac actin gene in embryonic

Figure 1. The $M$ region is required for expression in embryos directed by the cardiac actin promoter. $(A)$ Diagram of the $X e$ nopus cardiac actin gene promoter $(-417$ to +1$)$ showing the transcription initiation site (large arrow), TATA box (open rectangle), four CArG boxes (solid ovals), the $M$ region (crosshatched rectangle), and the series of deletions made in the promoter to identify essential distal regulatory sequences. $(B)$ The effect of promoter deletions on transcription of a Xenopus cardiac actin-human $\beta$-globin fusion gene injected into fertilized Xenopus eggs. The expression of each deletion construct (test) was compared with that obtained from a similar fusion gene (ref) containing the complete cardiac actin promoter extending to -580 attached to a truncated human $\beta$-globin transcription unit. RNA from cultured embryo fragments was analyzed by RNase protection to detect transcripts (arrowhead) from the injected genes (actin-globin) and from the endogenous cardiac actin gene. $(M)$ pBR Hinfl molecular weight markers; $(P)$ RNA probe; $(t)$ tRNA control. Animal caps comprising prospective epidermis were cultured in isolation $(-)$ or induced by conjugation with vegetal pieces to form axial structures, including embryonic muscle $(+)$. Lanes 5 and 6 are from a longer exposure of the autoradiograph, which reveals a low level of residual probe. $(C)$ The nucleotide sequence from -351 to -296 contains three E-box motifs (underlined) and corresponds to M3. One 20-nucleotide region shown separately as Ml, is centered on a 14-nucleotide sequence, which is similar to the consensusbinding site proposed for MyoD. somites by binding directly to a necessary region of the promoter.

\section{Results}

A cardiac actin promoter sequence required for gene activation in embryos

Previously, we defined two regions of the cardiac actin

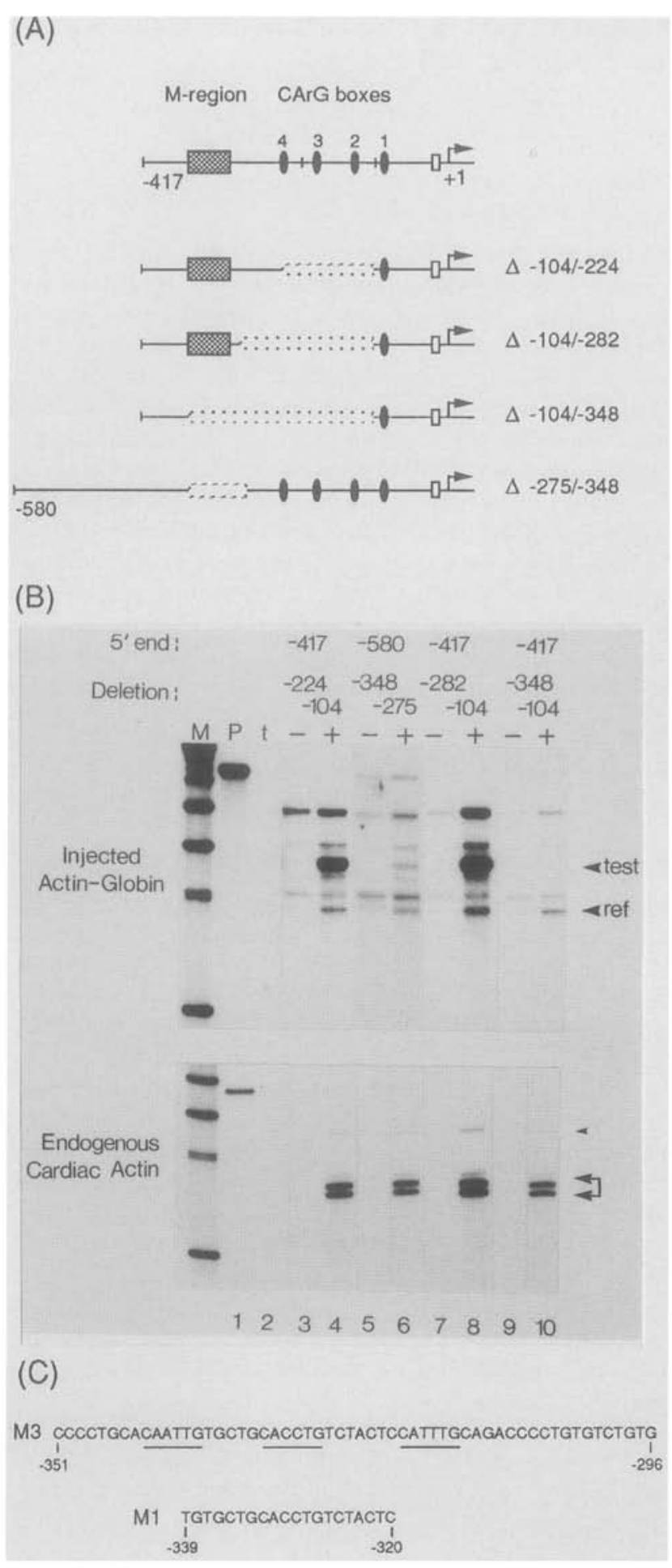


promoter that are essential for expression of the gene in Xenopus embryos: a CArG box, from -80 to -90 , and a more distal region, lying between -218 and -417 (Mohun et al. 1986, 1989). To identify the necessary sequences within this distal region, we tested the effect of internal deletions on transcription directed by the cardiac actin promoter (Fig. 1A).

Chimeric Xenopus cardiac actin-human $\beta$-globin fusion genes were injected into fertilized Xenopus eggs, and their expression was monitored by an RNase protection assay during differentiation of embryonic muscle. To estimate the quantitative effect of each deletion, a reference fusion gene containing an unmodified cardiac actin gene promoter was coinjected with the test gene (see Materials and methods). The specificity of transcription from the injected genes was assayed by an embryologic manipulation that we have used previously. Animal caps dissected from blastula embryos can be induced by vegetal pieces to differentiate into axial structures, a major one of which is muscle (Sudarwati and Nieuwkoop 1971), and express both endogenous and microinjected cardiac actin genes (Gurdon et al. 1985; Mohun et al. 1986, 1989). This manipulation is thought to mimic the events of mesoderm formation in normal development. In this study we compared RNA from these animal-vegetal conjugates with that from animal caps alone, which form atypical epidermis and do not express the cardiac actin gene.

Removal of the region from -104 to -224 placed the distal portion of the promoter $(-225$ to -417$)$ directly adjacent to CArG boxl and did not reduce expression of the test fusion gene (Fig. 1B, lanes 3 and 4) (Mohun et al. 1989). Similarly, increasing the extent of the internal deletion to encompass -104 to -282 left expression unaffected (lanes 7 and 8). When the deletion extended to -348 , however, expression of the fusion gene was virtually undetectable (lanes 9 and 10), indicating that a 3 ' boundary for essential sequences within this portion of the promoter lies between -282 and -348 . Furthermore, deletion of the region from -275 to -348 from the unmodified promoter was also sufficient to reduce dramatically expression of the fusion gene (lanes 5 and 6 ) and confirmed the importance of this region. We refer to the sequence from -282 to -348 as the "M-region" of the promoter.

\section{Temporal and spatial distribution of $M$-region-binding} activities during embryogenesis

We then used an electrophoretic mobility-shift assay (EMSA) to determine whether Xenopus embryos contain sequence-specific DNA-binding proteins that interact with the $M$ region. An oligonucleotide probe (M3) comprising almost the entire $M$ region $(-351$ to -296 ; Fig. 1C) was incubated with a whole-cell extract from stage18 neurula embryos, a stage when embryonic muscle has begun to differentiate and the cardiac actin gene is expressed. Four of the protein-M3 DNA complexes detected were shown to be specific by competition with unlabeled M3 oligonucleotide, but not with the unre- lated CArG boxl oligonucleotide (Fig. 2A). We have called them EMFl-4 for embryonic M-region factors. EMF2-4 are readily detected, whereas EMF1 is a minor component that migrates just above EMF2 and is poorly resolved in this experiment (but see Fig. 2B, lanes 5-7).

Figure 2B shows these binding activities in a series of extracts from successive stages of early development. EMFl is undetectable in egg extracts but detectable in embryo extracts from the early neurula stage onward. EMF3 and EMF4 are detectable at low levels in the egg, and their levels increase during early development. The level of EMF2 also increases somewhat, but other experiments indicate that any increase is comparatively small. In contrast, four proteins, including SRF, that bind specifically to CArG boxl are detected at an approximately constant level throughout this period (Mohun et al. 1989; Taylor 1991).

Having analyzed the temporal pattern of specific M3binding activities, we investigated their spatial distribution. In neurula embryos, cardiac actin expression is restricted to the myotomes, which make up almost all of the somites in Xenopus. We used an extract made from somites dissected from late neurulae in an EMSA with the M3 probe. EMF1-4 were detected, and each was competed by unlabeled M3 DNA (Fig. 2C). The sensitivity of the assay was such that extract from the somites of only two embryos was sufficient to generate a signal. EMF1 was relatively prominent in the somite extract compared with whole embryo extracts, suggesting that it is enriched in embryonic muscle cells.

Two lines of evidence support this view. First, EMF1 is undetectable in extracts of dissected neurectoderm, a nonmuscle tissue adjacent to the somites that differentiates to form a range of nonmuscle cell types, including nervous tissue and epidermis (Fig. 2C, cf. lanes 1 and 2). This contrasts with the distribution of the other bands, which are of similar intensity with each extract. The difference between the extracts is most striking when the detection of EMF1 is enhanced by omission of $\mathrm{Mg}^{2+}$ from the assay (Fig. 2C, lanes 3 and 4). Under these conditions, EMF2, which migrates closely to EMF1, binds poorly. Second, EMF1 is undetectable in extracts of belly pieces from stage-34 tadpoles (data not shown). These pieces contain a different range of nonmuscle cell types than those found in the neurectoderm. In summary, both the temporal and spatial distributions of EMF1 during Xenopus embryogenesis are consistent with a role for it in activating expression of the cardiac actin gene.

\section{Xenopus $M y o D$ can bind to the $M$ region}

Examination of the $M$ region sequence revealed three copies of the E-box motif, CANNTG (see Fig. 1C), which is common to the binding sites of several helix-loophelix (HLH) DNA-binding proteins (Murre et al. 1989a) and lies at the center of the mouse MyoD-binding site in the muscle creatine kinase (MCK) enhancer (Lassar et al. 1989). We therefore asked whether Xenopus MyoD could bind to the $M$ region. XMyoD protein prepared by translation in vitro of synthetic XMyoD RNA was used in an 


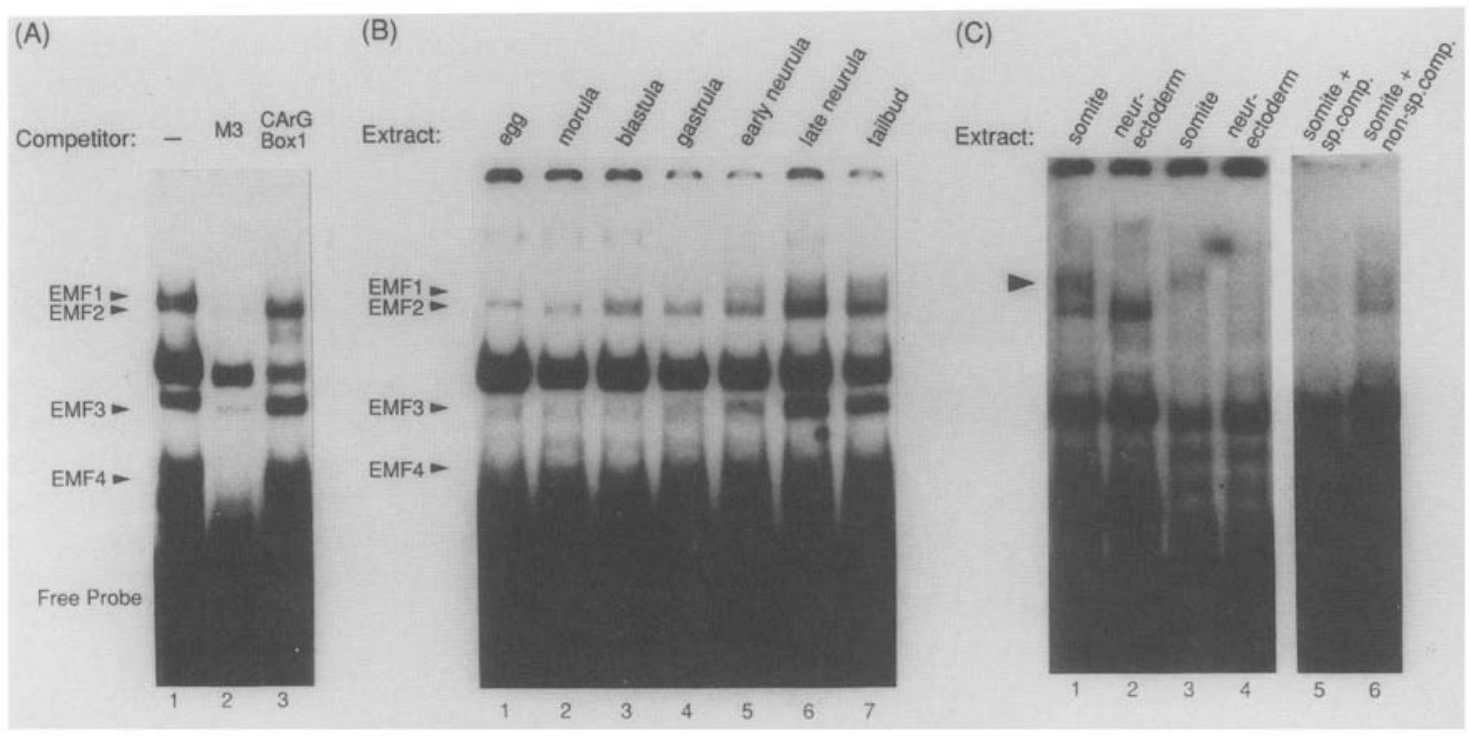

Figure 2. Temporal and spatial distribution of M-region-binding activities in embryo extracts. EMSAs are shown with embryo extracts and $\mathrm{M} 3$ probe. $\mathrm{MgCl}_{2}$ is included in the binding buffer, except where indicated, to detect each of EMF1-4. (A) Assay with stage-18 extract and competitors in each lane as follows: (Lane 1) None; (lane 2) $100 \mathrm{ng}$ of M3 oligonucleotide; (lane 3) $100 \mathrm{ng}$ of CArG box 1 oligonucleotide. $(B)$ Assay with extracts from half an embryo-equivalent from the indicated developmental stages. $(C)$ Assay with extracts from somites (lanes 1, 3,5, and 6) or from neuroectoderm (lanes 2 and 4). Lanes 3 and 4 lack $\mathbf{M g C l}_{2}$ in the binding assay; lane 5 includes the isolated M3 fragment as specific competitor DNA; and lane 6 includes the same amount of a nonspecific pBR fragment of the same length. A relatively long exposure of the autoradiograph is shown to demonstrate clearly competition of binding of the EMF1 complex. The specific complexes EMF1-4 are indicated by arrowheads $(A$ and $B) ; E M F 1$ is indicated by an arrowhead $(C)$. In $A$ another complex competed by both M3 and CArG boxl oligonucleotides probably corresponds to ECF4, a DNA-end-binding protein described elsewhere (Taylor 1991).

EMSA with the M3 probe. XMyoD does bind to M3 (Fig. 3, lane 5). The XMyoD-M3 interaction is specific for both the protein and the DNA probe. First, no specific complex is produced with either mock-translated reticulocyte lysate or with in-vitro-translated Xenopus SRF (lanes 1 and 2), which binds to cardiac actin CArG box l. Second, formation of the M3-XMyoD complex is competed by unlabeled M3 oligonucleotide, but not by CArG boxl (lanes 6, 7, and 9). The amount of complex formed on the M3 probe is similar to that formed in a binding assay with the same amount of $\mathrm{XMyoD}$ and an equivalent amount of probe containing the two MyoD-binding sites of the mouse MCK enhancer (Fig. 3, lanes 10-12). This indicates that the affinity of $\mathrm{XMyoD}$ is similar for each sequence.

The binding of $\mathrm{XMyoD}$ to $\mathrm{M} 3$ requires an intact first helix in its HLH domain, which suggests that XMyoD can bind as a homodimer to M3. The mutant XMyoD114P (Hopwood and Gurdon 1990) has a singleamino-acid substitution that disrupts the putative HLH domain, which in other systems is required for MyoD to dimerize with itself and other proteins and for subsequent DNA binding (Murre et al. 1989b; Davis et al. 1990). No specific complex was detectable using the same amount of XMyoD114P protein as was used in the assays with wild-type XMyoD (Fig. 3, lane 4).

The other member of the MyoD family characterized thus far in Xenopus is a probable homolog of the human gene Myf-5 (Hopwood et al. 1991). XMyoD and XMyf5 proteins are closely related; therefore, we asked whether XMyf 5 could also bind to the $\mathrm{E}$ boxes in the $\mathrm{M}$ region of the cardiac actin promoter. In contrast to the results obtained with XMyoD, no specific DNA-protein complex was detected when in vitro-translated XMyf5 was used in an EMSA with M3 DNA probe (Fig. 3, lane 3). XMyf5 can, however, participate in binding to M3 in combination with other proteins (see below).

\section{$X M y o D$ and EMF1 both bind to a 20-bp sequence within the $M$ region}

Of the three E-box motifs within the M3 sequence, only one shows extensive similarity to the 14-bp consensus originally proposed for the MyoD-binding site (Buskin and Hauschka 1989) and to the shorter consensus for MyoD-E2A heterodimers recently defined by the selection of binding sites from random oligonucleotides (Blackwell and Weintraub 1990). A 20-bp oligonucleotide (M1; see Fig. 1C) that encompasses this sequence binds $\mathrm{XMyoD}$ specifically (Fig. 4A, lanes $1-5$ ), and is an effective competitor of XMyoD binding to M3 (Fig. 3, lane 8). The affinity of XMyoD protein is similar for both $M 1$ and M3 (cf. Fig. 3, lane 5 with Fig. 4A, lane 3), indicating that the $\mathrm{M} 1$ sequence is the major component of the XMyoDbinding activity of $M 3$. However, dimethylsulfate interference assays using the M3 probe and XMyoD-GST (glutathionine-S-transferase) fusion protein show that in addition to binding at the M1 site, $\mathrm{XMyoD}$ can also 


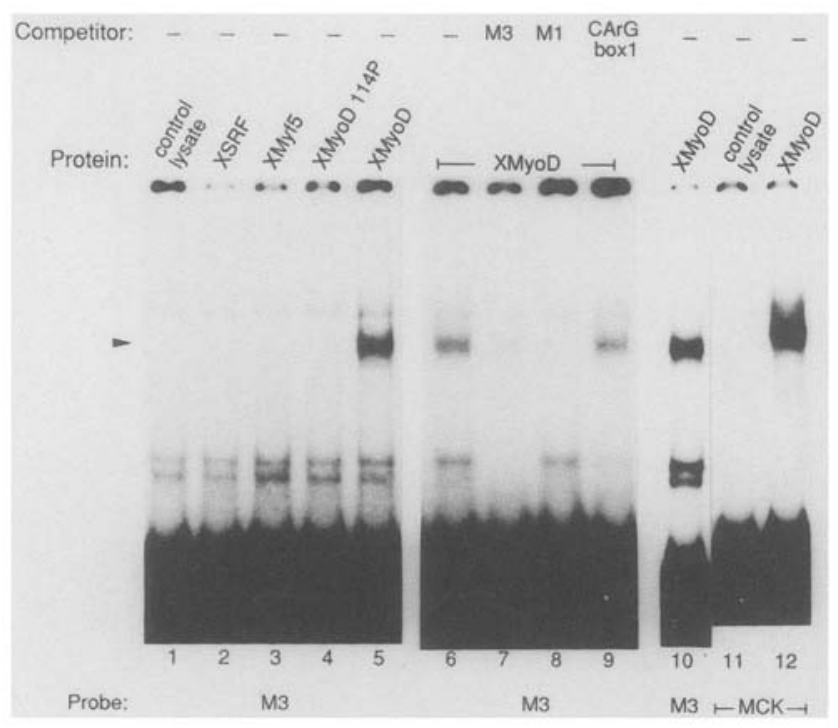

Figure 3. In vitro-translated $\mathrm{XMYOD}$ can bind to the cardiac actin promoter $M$ region. EMSA is shown with in vitro-translated proteins. (Lanes 1-5) M3 probe with mock-translated reticulocyte lysate (1); XSRF (2); XMyf5 (3); XMyoD114P (4); and XMyoD (5). (Lanes 6-9) M3 probe with XMyoD plus (6) no competitor; (7) $200 \mathrm{ng}$ of M3 oligonucleotide; (8) $200 \mathrm{ng}$ of M1 oligonucleotide; (9) $200 \mathrm{ng}$ of CArG boxl oligonucleotide. (Lanes 10-12) (10) M3 probe plus XMyoD; (11) MCK probe plus mocktranslated reticulocyte lysate; (12) MCK probe plus XMyoD. The arrowhead indicates the XMyoD-containing complex.

interact with the adjacent, upstream $\mathrm{E}$ box (data not shown).

Using the same 20-bp M1 probe, we detected a specific M1-binding activity (arrowhead) in embryo extracts with the temporal and spatial characteristics of the M3-binding activity EMF1 (Fig. 4B). The M1-binding activity was detectable in the staged extracts from early neurula onward (lanes 1-7) and was present in the extracts from somites, but not those from neurectoderm (lanes 8 and 9). It was specific, as shown by competition with unlabeled Ml oligonucleotide (lanes 10-12). In addition, M1 oligonucleotide competed formation of the somite EMF1-M3 complex (not shown). These results identify a 20-bp-binding site of EMF1 and suggest that XMyoD might be a component of the somite EMFl complex.

\section{EMF1 contains an XMyoD-related protein}

We tested the possibility that somite EMF1 contains $\mathrm{XMyoD}$ by using an antiserum raised against $\mathrm{XMyoD}$ GST fusion protein in an EMSA with the somite extract. Two approaches were used with both the M3 and M1 probes (Fig. 5). In the first, a "supershift" assay, the antibodies were added after the formation of the EMF1-M region DNA complex; and in the second, a depletion assay, the antibodies were added to the somite extract before the $M$ region DNA. The EMF1 complex was completely supershifted into a slower migrating band by the anti-XMyoD-GST serum (lanes 1-4). Similarly, the
EMF1 complex was completely removed in the depletion assay by both the anti-XMyoD-GST serum and anti$\mathrm{XMyoD}$ antibodies affinity-purified from this serum (lanes 5-10). In each approach the specificity of the antibody action was demonstrated by no effect of both preimmune serum (lanes 1, 3, 5, and 8) and anti-GST antibodies (not shown).

In whole-stage 18 embryo extracts, EMF1 was only just detectable (see Figs. 2B and 4B), but here too it was supershifted by the anti-XMyoD antibodies (not shown). No other complex, including EMF2-4 and any detected with the neurectoderm extract, was affected by inclusion of these antibodies in the binding reaction, indicating that they bound specifically to a component of the EMF1 complex. In addition, the anti-XMyoD antibodies did not cross-react with an XMyf5-containing complex (see below). We conclude that EMF1 contains XMyoD or an antigenically related protein.

\section{Mixing $X M y o D$ with neurectoderm extract produces a binding activity that comigrates with EMF1}

The complexes of in vitro-translated XMyoD and the $M$ region probes migrate substantially faster than the somite complex EMF1. We reasoned that if EMF1 contains $\mathrm{XMyoD}$, it does so in combination with other proteins. Because the myogenic proteins can form heterodimers-hetero-oligomers with other HLH proteins in vitro (Murre et al. 1989b; Davis et al. 1990), it is possible that EMFl is XMyoD complexed with another member of the HLH family. To investigate these other factors we tested whether nonmuscle extracts contain proteins that can reconstitute an EMF1-like-binding activity when mixed with XMyoD.

The addition of in vitro-translated $\mathrm{XMyoD}$ to neuroectoderm extract resulted in the appearance of an $\mathrm{M}$ region-binding activity that was undetectable with the unsupplemented neuroectoderm extract (Fig. 6A, lanes 14). No such complex was formed with neuroectoderm extract mixed with mock-translated reticulocyte lysate (lane 8), and the complex was specific, as demonstrated by competition with unlabeled binding site oligonucleotide (not shown). The new complex was also formed with a concentration of $\mathrm{XMyoD}$ below that required to detect binding of XMyoD alone (lanes 5-8), indicating that it had a binding affinity higher than XMyoD alone. The mobility of the complex was less than that of $\mathrm{XMyoD}$ alone (Fig. 6A, lanes 2 and 3 ) but, strikingly, was indistinguishable from that of somite EMF1 (Fig. 6B, lanes 1-4). Similarly, mixing XMyoD with somite extract produced more of the same mobility complex (not shown). These results suggest that EMF1 might be a complex between XMyoD and proteins that are not muscle specific. Association with these proteins requires an intact HLH domain, because XMyoD114P, which has a point mutation that disrupts the HLH motif, does not form the new complex when it is mixed with neuroectoderm extract (Fig. 6B, lanes 5 and 6).

Similar results were also obtained in mixing experiments using XMyf5 protein (Fig. 7) despite the lack of 


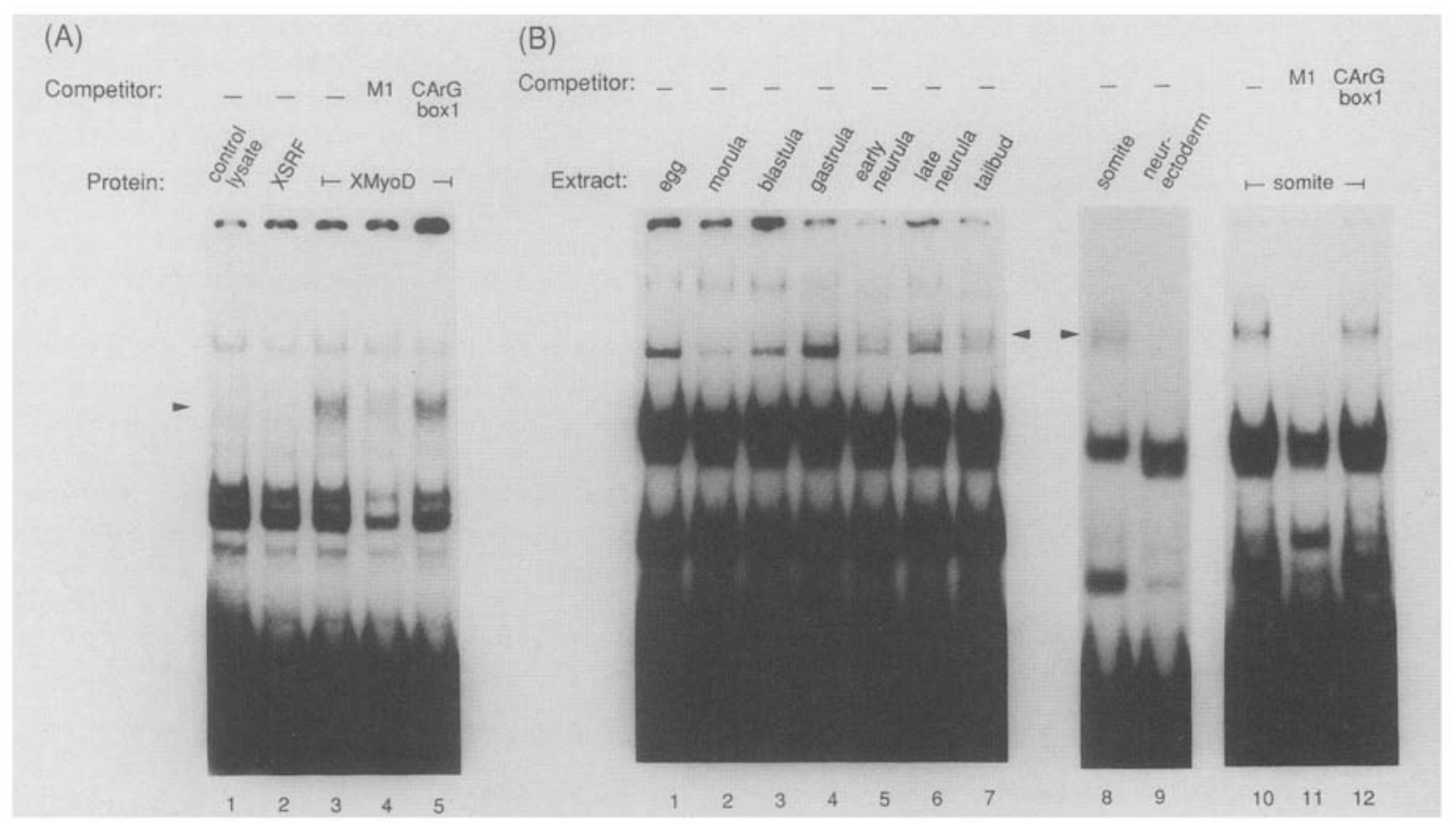

Figure 4. XMYoD and EMF1 both bind to a 20-bp E-box-containing sequence within the $M$ region. EMSA is shown with $M 1$ probe and protein in each lane as follows: $(A)$ (1) Mock-translated reticulocyte lysate; (2) XSRF; (3) XMyoD; (4) XMyoD plus 100 ng of M1 oligonucleotide; (5) XMyoD plus $100 \mathrm{ng}$ of CArG box l oligonucleotide. The arrowhead indicates the XMyoD-containing complex. $(B)$ (Lanes 1-7) Extracts from half an embryo-equivalent from the indicated developmental stages, with $\mathrm{MgCl}_{2}$ included in the binding buffer. (Lanes 8 and 9) Extracts from somites (8) and neuroectoderm (9). (Lanes 10-12) Extracts from somites plus the following: (10) No addition; (11) $100 \mathrm{ng}$ of Ml oligonucleotide; (12) $100 \mathrm{ng}$ of CArG boxl oligonucleotide. (Arrowhead) The EMF1 complex.

detectable binding of XMyf5 alone to the $M$ region. Thus, the complex between the neuroectoderm extract and XMyf5, as with XMyoD, has a higher binding affinity than the myogenic factor alone. Similarly, it also requires an intact HLH domain for its formation: No complex is detectable with XMyf5-102P, which has a point mutation in the HLH motif (Hopwood et al. 1991). However, the XMyf5-neuroectoderm complex migrates more rapidly than both somite EMF1 and the EMF1-like activity formed by mixing $\mathrm{XMyoD}$ and neuroectoderm extract (Fig. 6B, lanes 1-4; Fig. 7, lanes 4 and 6). This is consistent with predicted relative molecular masses of $32 \mathrm{kD}$ for XMyoD and $28 \mathrm{kD}$ for XMyf5 (Hopwood et al. 1989b, 1991).

We were then able to use the binding of XMyf5 to assess in the EMSA the specificity of the antibodies for $\mathrm{XMyoD}$ in comparison with XMyf5, the closest known relative of XMyoD in Xenopus. Incubation with antiXMyoD-GST serum or the affinity-purified anti-XMyoD antibodies, but not preimmune serum or anti-GST serum (not shown), completely removed the band corresponding to the XMyoD-containing complex formed by mixing XMyoD with stage-18 embryo extract (Fig. 8, lanes $1-3$ ). In contrast, the band corresponding to the XMyf5-containing complex was unaffected by these anti-XMyoD antibodies (Fig. 8, lanes 4-6). This demonstrates that under the conditions used in these assays, the antibodies do not cross-react with a complex containing XMyf5. The antibodies do, however, completely remove or supershift somite EMF1 (Fig. 5), which indicates that the complex formed between XMyf5 and embryo extract is not a detectable component of EMFl (see Discussion). We conclude that somite EMF1 is a complex between $\mathrm{XMyoD}$, or a similar protein, and another protein present in many, if not all, embryo tissues.

\section{The EMF1-binding activity is inducible in animal caps}

Animal caps can be diverted experimentally from their normal ectodermal pathway of differentiation to form mesodermal derivatives, including muscle. Extracts made from animal caps of stage- 8 blastulae, which had been induced to form mesoderm by incubation in XTCconditioned medium, were compared with extracts from uninduced animal caps in the EMSA with the M3 probe. An M3-binding activity, EMF1, was detectable in the extract from induced animal caps but was undetectable in the extract from uninduced animal caps (Fig. 9, lanes 1 and 2). This binding activity was specific, as shown by competition with unlabeled M3 oligonucleotide (lane 5), and was identified as EMF1 as follows: It was removed by incubation of the extract with the anti-XMyoD antiserum, but not preimmune serum, before the addition of the M3 probe (lanes 3 and 4), and it comigrated in the EMSA with the previously defined EMF1 (not shown). Similar results were obtained with extracts from animal caps induced by making conjugates with vegetal pieces of blastulae. 


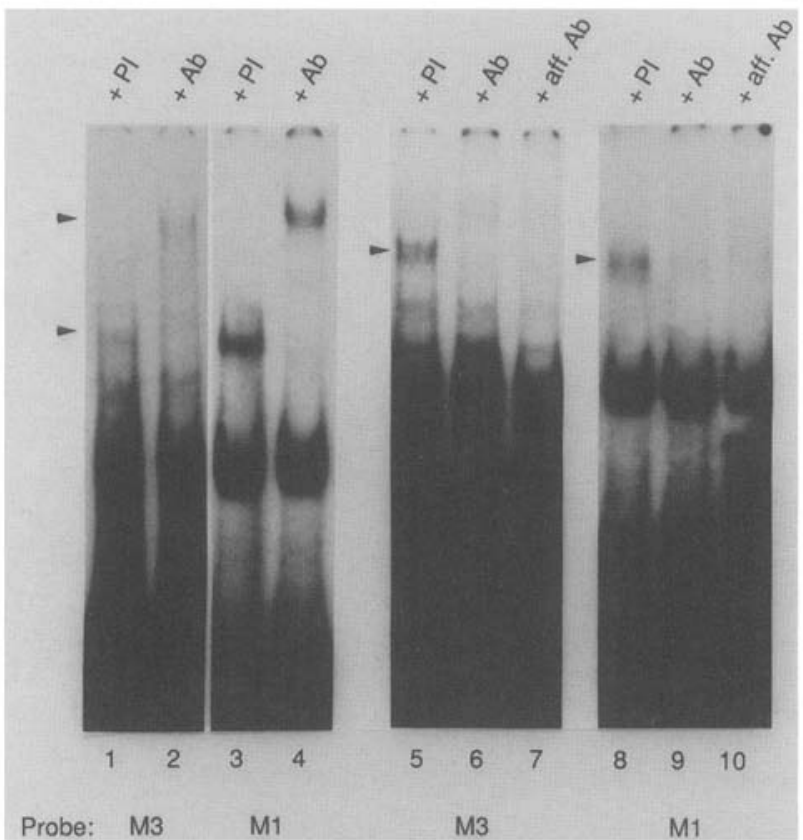

Figure 5. The EMF1-M region complex is recognized by antiXMyoD antibodies. EMSA with somite extract and M3 probe (lanes 1,2, and 5-7) or M1 probe (lanes 3,4, and 8-10). (Lanes 1-4) A supershift assay with either preimmune serum (+PI) or anti-XMyoD-GST serum $(+\mathrm{Ab})$. The EMF1 and supershifted complexes are indicated by arrowheads. (Lanes 5-10) A depletion assay with preimmune serum (+PI), anti-XMyoD-GST serum $(+\mathrm{Ab})$, or affinity-purified anti-XMyoD antibodies (+ aff. Ab). (Arrowheads) The EMF1 complexes.

\section{Discussion}

In this article we have shown that the $M$ region from -282 to -348 of the cardiac actin promoter is required for expression of this gene in embryos. Synthetic XMyoD can bind specifically to this region, probably as a homodimer, with an affinity similar to that of the mouse MCK enhancer. We have extended these findings by analyzing Xenopus embryo factors that interact with this MyoD-binding site. Early frog embryos can be dissected into discrete tissues, and we have exploited this to describe four specific $M$-region-binding activities that are present in somites. Any of these could be required for cardiac actin expression. However, one of them, EMF1, is first detectable when cardiac actin transcripts begin to accumulate and appears to be restricted to embryonic muscle. This suggests a simple model in which EMF1 binding to the $M$ region of the cardiac actin promoter results in tissue-specific activation of the gene.

Our results indicate that one component of EMF1 is XMyoD: (1)EMF1 is detectable in embryonic muscle but not in a variety of nonmuscle tissues; (2) EMF1, as with XMyoD (Hopwood et al. 1989b), is detectable in animal caps induced to form muscle but not in uninduced animal caps; (3) EMF1 is not detectable in UV-treated embryos (not shown), which contain no muscle (Scharf and Gerhart 1980) or XMyoD RNA (N.D. Hopwood and K.
Kao, unpubl.); (4) EMF1 is first readily detectable in early neurulae, and long exposures of autoradiographs indicate a low level in gastrulae; (5) EMF1 binds to a 20-bp promoter sequence containing a 14-bp MyoD-binding site consensus; and (6) anti-XMyoD antibodies bind to EMF1. Our results also suggest that EMF1 is an HLH domaindependent complex, a dimer or higher order multimer, between $\mathrm{XMyoD}$ and other proteins found in nonmuscle tissues, as well as in somites. This protein could be a product of the Xenopus E2A gene (Murre et al. 1989a; Kamps et al. 1990|. Consistent with this idea, the complex between XMyoD and neurectoderm extract shares several properties with the MyoD-E12 complex (Murre et al. 1989b; Davis et al. 1990): Both migrate more slowly and have a higher binding affinity than MyoD alone, and both can form post-translationally.

Experiments with cultured cells in which MyoD induced muscle differentiation in nonmuscle cell lines suggest that it plays a critical role in establishing muscle differentiation (Davis et al. 1987; Weintraub et al. 1989). MyoD also appears to participate in the activation of several genes expressed during the terminal differentiation of muscle cells. Thus, the mouse MCK enhancer binds both synthetic MyoD and a complex from a muscle cell line that interacts with anti-MyoD antibodies (Lassar et al. 1989). Moreover, this binding site is required for full enhancer activity (Buskin and Hauschka 1989; Lassar et al. 1989) and is sufficient for transcriptional activation by MyoD after transfection into $\mathrm{C} 3 \mathrm{H} /$ 10T1/2 fibroblasts (Weintraub et al. 1990). Synthetic MyoD has also been shown to bind functionally to important sites in the acetylcholine receptor $\alpha$-subunit gene promoter, the myosin light-chain $1 / 3$ enhancer (Braun et al. 1990; Piette et al. 1990) and, most recently, the human cardiac actin promoter (Sartorelli et al. 1990). In this last case, mutation of the MyoD-binding site, which lies between the TATA box and the most proximal CArG box, greatly reduces expression from the promoter in both muscle cell lines and nonmuscle cell lines supplied with MyoD. The site may therefore play an analogous role to the $\mathrm{M}$ region of the Xenopus gene, despite the difference in its location and the presence of only a single binding motif, which contrasts with the multiple sites in the Xenopus gene and the other muscle gene promoter-enhancers that bind MyoD (Lassar et al. 1989; Piette et al. 1990; Rosenthal et al. 1990).

Although much progress has resulted from studies of cultured cells, it is important to assess the role of $\mathrm{MyoD}$ during embryogenesis, when developmental fate decisions are made and muscle is differentiating normally. In the Xenopus embryo, XMyoD transcripts accumulate, above a low maternal level, in the presumptive somitic mesoderm of the gastrula $\sim 2 \mathrm{hr}$ before cardiac actin transcripts first appear (Hopwood et al. 1989b). This pattern of expression is consistent with a function for XMyoD in the early events of myogenesis in the frog embryo, including the activation of the cardiac actin gene. This latter role is suggested by the finding that in the Xenopus embryo ectopic expression of XMyoD, but not the HLH domain mutant XMyoD114P, activates the cardiac actin 

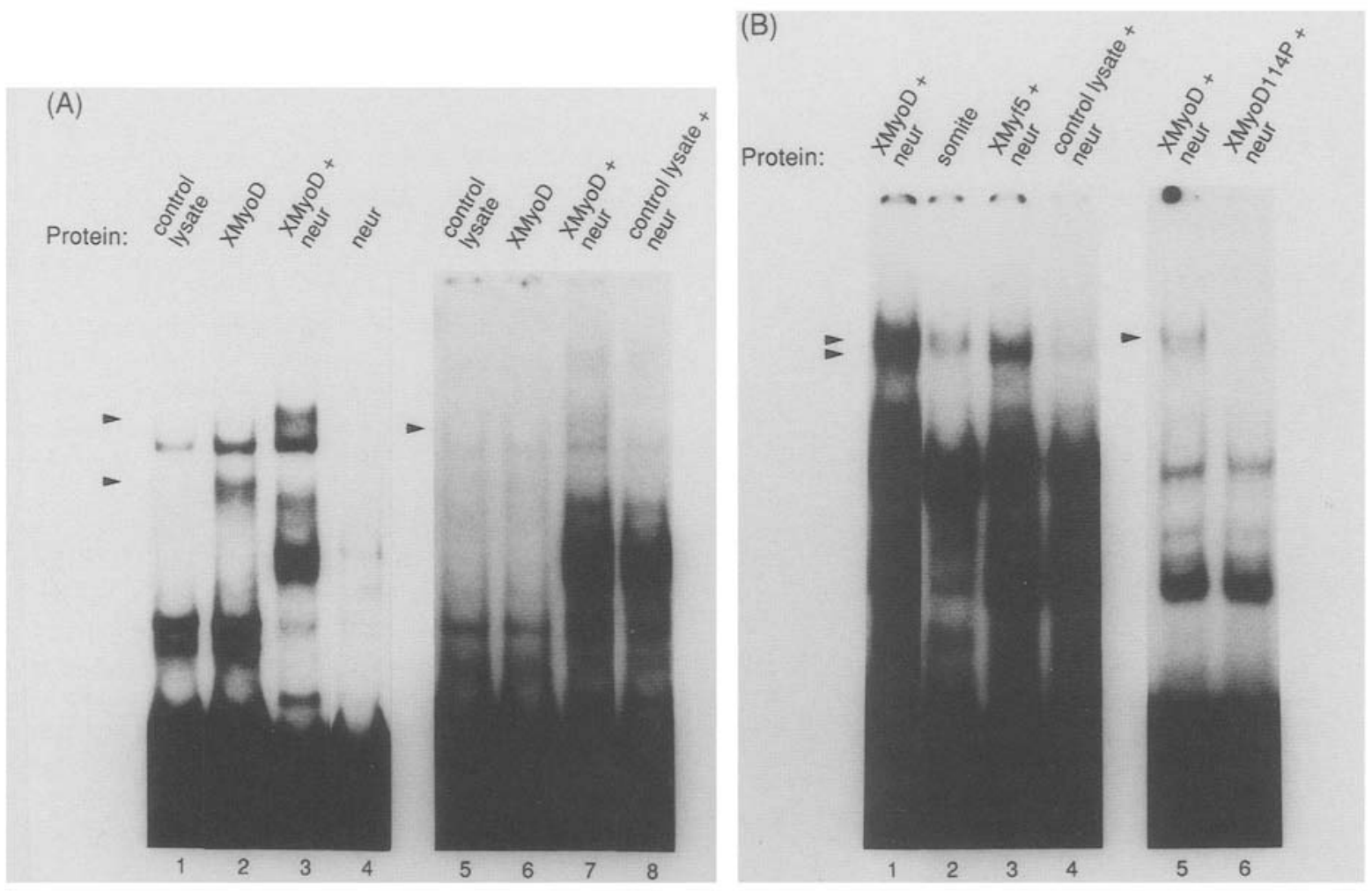

Figure 6. Mixing XMyoD with neuroectoderm extract produces an $M$ region-binding complex that comigrates with EMF1. $(A)$ EMSA with M3 probe and protein in each lane as follows: (1) Mock-translated reticulocyte lysate; $(2)$ XMyoD; $(3)$ XMyoD plus neuroectoderm extract; (4) neuroectoderm; (5) mock-translated reticulocyte lysate; $(6)$ XMyoD; (7) XMyoD plus neuroectoderm; $(8)$ mock-translated reticulocyte plus neuroectoderm. Lanes 5-8 have fivefold less XMyoD or control lysate. (Lower arrowhead) The XMyoD complex; (upper arrowhead) the complex obtained by mixing XMyoD with neuroectoderm extract. $(B)$ EMSA with Ml probe and protein in each lane as follows: (1) XMyoD plus neuroectoderm extract; (2) somite extract; (3) XMyf5 plus neuroectoderm; (4) mock-translated reticulocyte lysate plus neuroectoderm; $(5)$ XMyoD plus neuroectoderm; $(6)$ XMyoD114P plus neuroectoderm. Complexes obtained by mixing neuroectoderm extract with XMyoD (upper arrowhead) and XMyf5 (lower arrowhead).

gene in cells that would not normally express it (Hopwood and Gurdon 1990). Somite-specific activation of the cardiac actin gene could therefore be a direct consequence of localized XMyoD expression in early somitic mesoderm. Such an effect might be direct through binding to the cardiac actin promoter, or indirect through the activation of other factors that regulate muscle differentiation. A major result of the work presented here is that normal embryo somites contain a MyoD-like factor that binds to the cardiac actin promoter in vitro. Moreover, in animal caps induced to form mesoderm in which transcription from the cardiac actin is strongly activated, the $\mathrm{XMyoD}$-containing EMFl-binding activity is also induced. These results suggest a direct mechanism and a model in which XMyoD is the muscle-specific component of a DNA-binding complex that interacts with a site necessary for activity of the cardiac actin promoter.

The regulation of cardiac actin expression in Xenopus development is, however, likely to be more complex in several respects than this simple model suggests. First, other myogenic factors may have a role in activating cardiac actin expression. Ectopic expression of XMyf5, as with XMyoD, can activate the cardiac actin gene in $\mathrm{Xe}$ nopus embryos (Hopwood et al. 1991); and we show here that XMyf5 can, in combination with other embryo proteins, bind to the $M$ region. XMyf5 is probably not detected as a component of EMFl as it is found mainly in posterior mesoderm at the stage when the somites were dissected (Hopwood et al. 1991), which would not have been included in our dissections. Second, although promoter elements other than the $M$ region, including CArG box1, may not establish muscle-specific transcription, they may be required to sustain the high levels of transcription characteristic of differentiating muscle. Finally, in vertebrates the cardiac actin gene is coexpressed with its skeletal counterpart in both the developing heart and the axial musculature of the embryo (Minty et al. 1982; Mohun et al. 1984; Sassoon et al. 1988). Because MyoD is not detectable in either embryonic or adult heart (Davis et al. 1987; Hopwood et al. 1989b; Sassoon et al. 1989), a second, MyoD-independent mechanism must be responsible for activating the cardiac actin gene in cardiac muscle.

\section{Materials and methods}

Promoter analysis

Internal promoter deletions were introduced into the Xenopus 


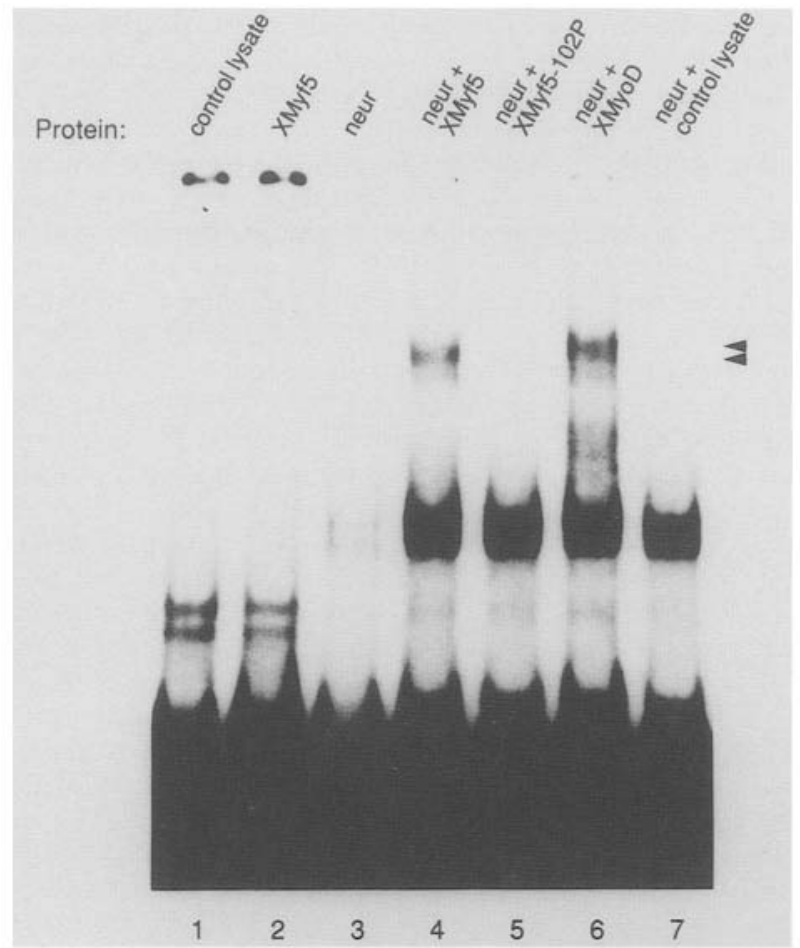

Figure 7. Mixing XMyf5 with neuroectoderm extract produces an M-region-binding complex. EMSA is shown with M3 probe and protein in each lane as follows: (1) Mock-translated reticulocyte lysate; (2) XMyf5; (3) neuroectoderm extract. Lanes 4-7 are neuroectoderm extract plus (4) XMyf5; (5) XMyf5-102P; (6) $\mathrm{XMyoD}$; and (7) mock-translated reticulocyte lysate. The binding activity produced by mixing XMyf 5 with neuroectoderm extract is specific, as it is competed by unlabeled M3 oligonucleotide (not shown), and is dependent on XMyf5, as it is not formed by mixing mock-translated reticulocyte lysate with neuroectoderm extract. The complexes obtained by mixing neuroectoderm extract with XMyoD (upper arrowhead) and XMyf5 (lower arrowhead) are indicated.

cardiac actin-human $\beta$-globin gene by recombining fragments from KpnI-linker scan mutations described previously (Mohun et al. 1989). Excision of the fusion gene as a ScaI-HindIII fragment followed by recloning resulted in truncation of the deleted promoters from -580 to -417 . Linearized test and reference plasmids (Mohun et al. 1989), $175 \mathrm{pg}$ in $7 \mathrm{nl}$, were injected into each blastomere of two-cell embryos in a ratio of $5: 1$. At the blastula stage, animal pole explants were dissected and cultured either as pairs or as conjugates with vegetal portions of uninjected blastulae (Gurdon et al. 1985). Explants were frozen when sibling, uninjected embryos had completed neurulation. RNA was extracted and analyzed as described previously (Mohun et al. 1989). In addition to protection by authentic transcripts from the injected genes, a number of bands are obtained that result from incomplete removal of injected DNA from the samples and indicate the presence of material in the assays of uninduced animal caps. The cardiac actin probe also detects transcripts from the endogenous gene: Two bands are revealed that result from the use of two polyadenylation signals (Mohun et al. 1986).

\section{Probes}

Oligonucleotidenucleotides for M3 and M1 (upper strands shown in Fig. 1C) were synthesized with KpnI-compatible ends and cloned into the KpnI site of the pUC18 polylinker. Probes were prepared by excising the insert with EcoRI and BamHI, and end-labeling with Klenow fragment and $\left[\alpha^{-32} \mathrm{P}\right] \mathrm{dATP}$. The CArG boxl probe was as described (Mohun et al. 1991), and the MCK probe was made from the plasmid pUC-E (Buskin and Hauschka 1989) by excising and end-labeling the 110-bp AvaI$\mathrm{Ncol}$ fragment containing the two defined MyoD-binding sites of the MCK enhancer.

\section{Embryo extracts}

Embryos were staged according to Nieuwkoop and Faber (1967). The staged extracts were made from unfertilized eggs, and from morula (stage 6.5), blastula (stage 8-9), gastrula (stage 11-12), early neurula (stage 14-15), late neurula (stage 18), and tailbud (stage 24) embryos. The somite dissections, from stage 18-20 neurulae, comprised the anterior segmented region plus a similar amount of immediately posterior unsegmented somitic mesoderm. The corresponding neuroectoderm dissection comprised the adjacent neural tissue, including neural crest, together with the surrounding epidermis. The stage- 34 belly piece was that remaining after the removal of the head, the axial and tail region, and the anterior ventral region containing the heart. Animal caps dissected from stage- 8 blastulae were either cultured untreated or induced by culturing for $4 \mathrm{hr}$ in a one-third dilution of heat-treated conditioned medium from XTC cells. Extracts were made when sibling embryos had completed neurulation. Whole-cell extracts were made on ice by homogenization of embryos or embryo pieces: 30 whole embryos in $300 \mu \mathrm{l}$, 20 somite/neurectoderm dissections in $50 \mu \mathrm{l}$, 30 belly dissections in $55 \mu \mathrm{l}$, and 30 induced or uninduced animal caps in $45 \mu \mathrm{l}$ of homogenization buffer [ $50 \mathrm{~mm}$ Tris- $\mathrm{HCl}(\mathrm{pH} 7.9), 25 \%$ glyc-

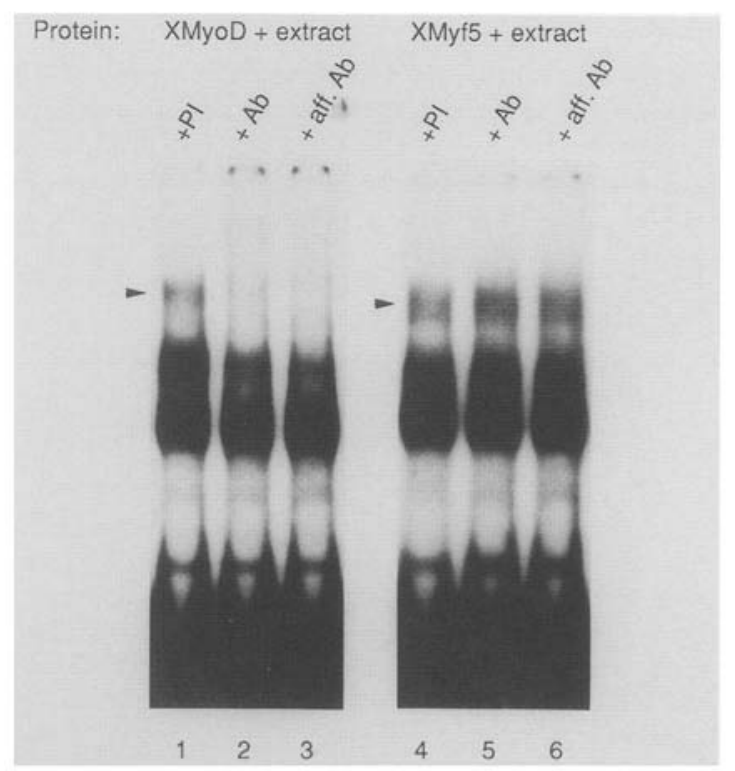

Figure 8. Anti-XMyoD antibodies recognize the binding activity produced by mixing XMyoD, but not XMyf5, with embryo extract. Complexes (arrowhead) formed by mixing stage- 18 extract with XMyoD (lanes 1-3) or XMyf5 (lanes 4-6) on M3 probe visualized by EMSA. Additions were as follows: (Lanes 1,4$)$ Preimmune serum $(+\mathrm{PI})$; (lanes 2,5) anti-XMyoD-GST serum $(+\mathrm{Ab}) ;($ lanes 3,6$)$ affinity-purified anti-XMyoD antibodies $(+$ aff. $\mathrm{Ab})$. 


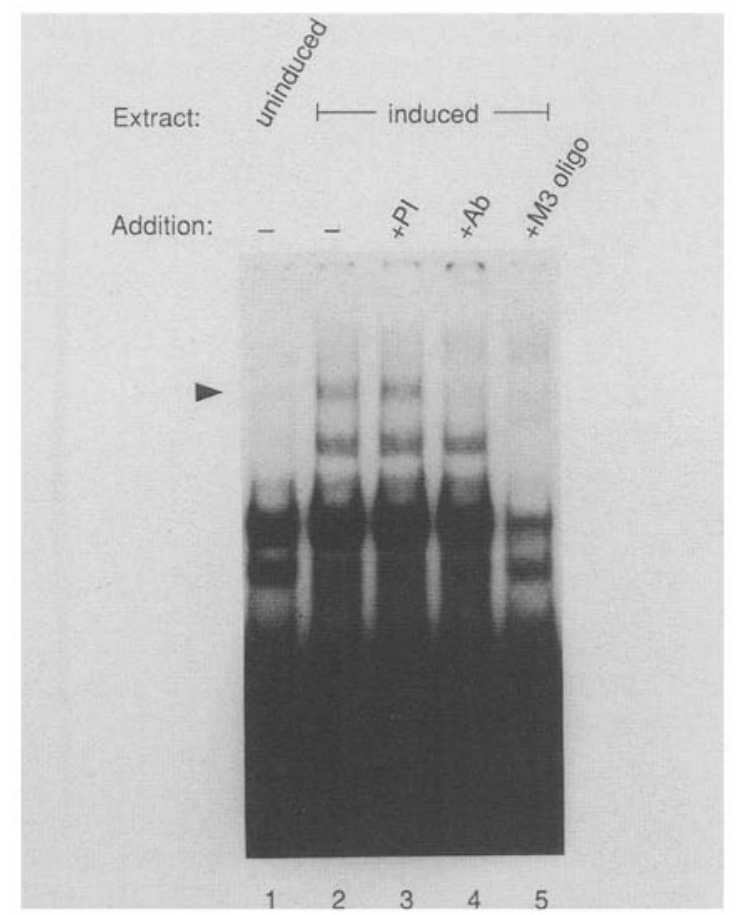

Figure 9. EMFl is inducible in animal caps. Complexes formed between extracts from uninduced (lane 1) and induced (lanes 2-5) animal caps on M3 probe visualized by EMSA. Additions were as follows: (Lanes 1 and 2) None; (lane 3) preimmune serum ( + PI); (lane 4) anti-XMyoD-GST serum (+ Ab); (lane 5) 100 ng of M3 oligonucleotide (+M3 oligo). (Arrowhead) The EMF1 complexes.

erol, $50 \mathrm{~mm} \mathrm{KCl}, 2 \mathrm{~mm}$ DTT, $0.5 \mathrm{~mm}$ PMSF, $0.1 \mathrm{~mm}$ EDTA, 25 $\mu \mathrm{g} / \mathrm{ml}$ aprotinin, $25 \mu \mathrm{g} / \mathrm{ml}$ leupeptin, $10 \mu \mathrm{g} / \mathrm{ml}$ bestatin]. The homogenate was centrifuged $\left(13,000 \mathrm{~g}\right.$ for $10 \mathrm{~min}$ at $\left.4^{\circ} \mathrm{C}\right)$, and the resulting supernatant was cleared by two further centrifugations $\left(13,000 \mathrm{~g}\right.$ for $5 \mathrm{~min}$ at $\left.4^{\circ} \mathrm{C}\right)$ and stored at $-80^{\circ} \mathrm{C}$.

\section{In vitro translation}

The SP6 vectors containing XMyoD, XMyf5, the corresponding point mutants XMyoD-114P and XMyf5-102P, and XSRF have been described (Hopwood and Gurdon 1990; Hopwood et al. 1991; Mohun et al. 1991). In both mutants a single-base-pair change introduces a helix-disrupting proline residue into the first helix of the HLH domain. Trace-labeled, capped RNA was synthesized from each of the five plasmids (Krieg and Melton 1987) and translated in vitro using a rabbit reticulocyte lysate (Jackson and Hunt 1983) containing [ ${ }^{35}$ S/methionine. The protein yield was estimated by TCA precipitation. Translation products were monitored by SDS-PAGE and visualized by autoradiography.

\section{EMSA}

The standard binding reaction $(15 \mu l)$ contained 4 fmoles of DNA probe in $37 \mathrm{mM} \mathrm{KCl}, 23 \mathrm{~mm}$ Tris- $\mathrm{HCl}(\mathrm{pH} 7.9), 3 \mathrm{~mm}$ HEPES (pH 7.9), $1 \mathrm{~mm}$ EDTA, $1 \mathrm{~mm}$ DTT, $0.5 \mathrm{~mm}$ PMSF, $14 \%$ glycerol and $1 \mu \mathrm{g}$ poly[d(I-C)]/poly[d(I-C)]. $\mathrm{MgCl}_{2}(2 \mathrm{mM})$ was included in some experiments, as indicated, to detect binding of each of EMF1-4. However, binding of both EMF1 and in vitro- translated XMyoD was detected more clearly without $\mathrm{MgCl}_{2}$. Protein $[5 \mu]$ of embryo extract or $\sim 60$ fmoles of specific protein (unless stated otherwise) made by in vitro translation] was added last, the mix was incubated for $20 \mathrm{~min}$ at room temperature, and the complexes were analyzed on $5 \%$ acrylamide/0.56 $\times$ TBE gels. In the comparison of binding between M1, M3, and MCK probes, the same amount of protein from the same in vitro synthesis was used. The assays with in vitrotranslated XMyoD contained a 15 -fold molar excess of protein over DNA, compared with the 100-1000-fold molar excesses used in many previous studies of other putative MyoD-binding sites (Lassar et al 1989; Braun et al. 1990; Piette et al. 1990; Rosenthal et al. 1990; Weintraub et al. 1990). In assays with mixed samples, embryo extracts were incubated with products of in vitro translation for $5 \mathrm{~min}$ at room temperature before the addition of probe. To make double-stranded competitor binding sites, upper and lower strand gel-purified oligonucleotides were annealed by heating to $65^{\circ} \mathrm{C}$ in $10 \mathrm{~mm}$ Tris- $\mathrm{HCl}(\mathrm{pH} 8), 5 \mathrm{~mm}$ $\mathrm{MgCl}_{2}$, followed by slow cooling. Alternatively, competitor DNAs were isolated by restriction enzyme digestion of the appropriate plasmid and subsequent electrophoresis and elution of the desired band. The assays in conjunction with antibodies were as follows. A $1 / 25$ dilution $(2 \mu \mathrm{l})$ of unpurified antiserum or affinity-purified antibodies was added to the protein mix and incubated for $15 \mathrm{~min}$ on ice before the addition of the DNA. The incubation was continued for $15 \mathrm{~min}$ at room temperature before analysis by $5 \%$ acrylamide gel electrophoresis. For the supershift assay the antiserum was added to the DNA-protein complexes formed in the standard way and the incubation continued for $15 \mathrm{~min}$ on ice before analysis on a $3.5 \%$ gel.

\section{Antibody production and purification}

A plasmid for expression in Escherichia coli of XMyoD fused to GST was made by cloning an AluI fragment of XMyoD2-24 (nucleotides 143-723) (Hopwood et al. 1989b) into the SmaI site of pGEX-3X (Smith and Johnson 1988). Protein for immunization of rabbits was purified essentially as described (Smith and Johnson 1988). Anti-GST antibodies were removed by incubation with CNBr-activated Sepharose $4 \mathrm{~B}$ coupled to GST, and anti-XMyoD antibodies were purified by affinity chromatography on $\mathrm{CNBr}-$ Sepharose $4 \mathrm{~B}$ coupled to the XMyoD fusion protein.

\section{Acknowledgments}

We thank Jean Buskin and Steve Hauschka for the pUC-E plasmid, Janet Heasman for XTC-conditioned medium and Kazuto Kato and Ken Kao for advice on its use, Nick Torpey for antiGST antiserum, and Colin Sharpe and Jeremy Rashbass for comments on the manuscript. We are grateful for the financial support of the Cancer Research Campaign, the Royal Society, and the Medical Research Council.

The publication costs of this article were defrayed in part by payment of page charges. This article must therefore be hereby marked "advertisement" in accordance with 18 USC section 1734 solely to indicate this fact.

\section{References}

Blackwell, T.K. and H. Weintraub. 1990. Differences and similarities in DNA-binding preferences of MyoD and E2A protein complexes revealed by binding site selection. Science 250: 1104-1110. 
Braun, T., E. Bober, B. Winter, N. Rosenthal, and H. Arnold. 1990. Myf-6, a new member of the human gene family of myogenic determination factors: Evidence for a gene cluster on chromosome 12. EMBO /. 9: 821-831.

Buskin, J. and S. Hauschka. 1989. Identification of a myocyte nuclear factor that binds to the muscle-specific enhancer of the mouse muscle creatine kinase gene. Mol. Cell. Biol. 9: $2627-2640$.

Cascio, S. and J. Gurdon. 1986. The timing and specificity of actin gene activation in early Xenopus development. UCLA Symp. Mol. Cell. Biol. 51: 195-204.

Davis, R., H. Weintraub, and A. Lassar. 1987. Expression of a single transfected cDNA converts fibroblasts to myoblasts. Cell 51: 987-1000.

Davis, R., P.-F. Cheng, A. Lassar, and H. Weintraub. 1990. The MyoD DNA binding domain contains a recognition code for muscle-specific gene activation. Cell 60: 733-746.

Gurdon, J., S. Fairman, T. Mohun, and S. Brennan. 1985. Activation of muscle-specific actin genes in Xenopus development by an induction between animal and vegetal cells of a blastula. Cell 41: 913-922.

Harvey, R. 1990. The Xenopus MyoD gene: An unlocalised maternal mRNA predates lineage-restricted expression in the early embryo. Development 108: 669-680.

Hopwood, N. and J. Gurdon. 1990. Activation of muscle genes without myogenesis by ectopic expression of MyoD in frog embryo cells. Nature 347: 197-200.

Hopwood, N., A. Pluck, and I. Gurdon. 1989a. A Xenopus mRNA related to Drosophila twist is expressed in response to induction in the mesoderm and the neural crest. Cell 59: 893-903.

- $1989 \mathrm{~b}$. MyoD expression in the forming somites is an early response to mesoderm induction in Xenopus embryos. EMBO I. 8: 3409-3417.

- 1991. Xenopus Myf-5 marks early muscle cells and can activate muscle genes ectopically in early embryos. Devel opment 111: 551-560.

Jackson, R. and R.T. Hunt. 1983. Preparation and use of nuclease-treated rabbit reticulocyte lysates for the translation of eukaryotic messenger RNA. Methods Enzymol. 96: 5074.

Kamps, M., C. Murre, X.-H. Sun, and D. Baltimore. 1990. A new homeobox gene contributes the DNA binding domain of the $t(1 ; 19)$ translocation protein in pre-B ALL. Cell 60: $547-555$.

Krieg, P. and D. Melton. 1987. In vitro RNA synthesis with SP6 RNA polymerase. Methods Enzymol. 155: 397-415.

Lassar, A., J. Buskin, D. Lockshon, R. Davis, S. Apone, S. Hauschka, and H. Weintraub. 1989. MyoD is a sequencespecific DNA binding protein requiring a region of myc homology to bind to the muscle creatine kinase enhancer. Cell 58: $823-831$.

Minty, A. and L. Kedes. 1986. Upstream regions of the human cardiac actin gene that modulate its transcription in muscle cells: Presence of an evolutionarily conserved repeated motif. Mol. Cell. Biol. 6: 2125-2136.

Minty, A., S. Alonso, M. Caravatti, and M. Buckingham. 1982. A fetal skeletal muscle actin mRNA in the mouse and its identity with cardiac actin mRNA. Cell 30: 185-192.

Mohun, T., S. Brennan, N. Dathan, S. Fairman, and J. Gurdon. 1984. Cell type-specific activation of actin genes in the early amphibian embryo. Nature 311: 716-721.

Mohun, T., N. Garrett, and J. Gurdon. 1986. Upstream sequences required for tissue-specific activation of the cardiac actin gene in Xenopus laevis embryos. EMBO J. 5: 3185 3193.

Mohun, T., M. Taylor, N. Garrett, and J. Gurdon. 1989. The
CArG promoter sequence is necessary for muscle-specific transcription of the cardiac actin gene in Xenopus embryos. EMBO I. 8: 1153-1161.

Mohun, T., A. Chambers, N. Towers, and M. Taylor. 1991. Expression of genes encoding the transcription factor SRF during early development of Xenopus laevis: Identification of a CArG box binding activity as SRF. EMBO J. 10: 933-940.

Murre, C., P. McCaw, and D. Baltimore. 1989a. A new DNA binding and dimerisation motif in immunoglobulin enhancer binding, daughterless, $M y o D$, and myc proteins. Cell 56: $777-783$.

Murre, C., P. McCaw, H. Vaessin, M. Caudy, L. Jan, Y. Jan, C. Cabrera, J. Buskin, S. Hauschka, A. Lassar, H. Weintraub, and D. Baltimore. 1989b. Interactions between heterologous helix-loop-helix proteins generate complexes that bind specifically to a common DNA sequence. Cell 58: 537-544.

Muscat, G. and L. Kedes. 1987. Multiple 5'-flanking regions of the human $\alpha$-skeletal actin gene synergistically modulate muscle-specific expression. Mol. Cell. Biol. 7: 4089-4099.

Nieuwkoop, P. and J. Faber. 1967. Normal table of Xenopus laevis (Daudin). North Holland, Amsterdam.

Piette, J., J.-L. Bessereau, M. Huchet, and J.-P. Changeux. 1990. Two adjacent MyoDl-binding sites regulate expression of the acetylcholine receptor $\alpha$-subunit gene. Nature 345: 353355 .

Quitschke, W., L. DePonti-Zilli, Z.-Y. Lin, and B. Paterson. 1989. Identification of two nuclear factor-binding domains on the chicken cardiac actin promoter: Implications for regulation of the gene. Mol. Cell. Biol. 9: 3218-3230.

Rosenthal, N., E. Beglund, B. Wentworth, M. Donoghue, B. Winter, E. Bober, T. Braun, and H. Arnold. 1990. A highly conserved enhancer downstream of the human $\mathrm{MLC} 1 / 3$ locus is a target for multiple myogenic determination factors. $\mathrm{Nu}$ cleic Acids Res. 18: 6239-6246.

Sartorelli, V., K. Webster, and L. Kedes. 1990. Muscle-specific expression of the cardiac $\alpha$-actin gene requires MyoD1, CArG-box binding factor, and Spl. Genes \& Dev. 4: 18111822.

Sassoon, D., I. Garner, and M. Buckingham. 1988. Transcripts of $\alpha$-cardiac and $\alpha$-skeletal actins are early markers for myogenesis in the mouse embryo. Development 104: 155-164.

Sassoon, D., G. Lyons, W. Wright, V. Lin, A. Lassar, H. Weintraub, and M. Buckingham. 1989. Expression of two myogenic regulatory factors myogenin and $\mathrm{MyoD} 1$ during mouse development. Nature 341: 303-307.

Scales, J., E. Olson, and M. Perry. 1990. Two distinct Xenopus genes with homology to $\mathrm{MyoDl}$ are expressed before somite formation in early embryogenesis. Mol. Cell. Biol. 10: 15161524.

Scharf, S. and J. Gerhart. 1980. Determination of the dorsalventral axis in eggs of Xenopus laevis: Complete rescue of UV-impaired eggs by oblique orientation before first cleavage. Dev. Biol. 79: 181-198.

Smith, D. and K. Johnson. 1988. Single-step purification of polypeptides expressed in Escherichia coli as fusions with glutathione S-transferase. Gene 67: 31-40.

Sudarwati, S. and P. Nieuwkoop. 1971. Mesoderm formation in the anuran Xenopus laevis (Daudin). Wilhelm Roux's Arch. Entw. Mech. Org. 166: 189-204.

Taylor, M. 1991. A family of muscle gene promoter element (CArG) binding activities in Xenopus embryos: CArG/SRE discrimination and distribution during myogenesis. Nucleic Acids Res. 19: 2669-2675.

Taylor, M., R. Treisman, N. Garrett, and T. Mohun. 1989. Muscle-specific (CArG) and serum-responsive (SRE) promoter elements are functionally interchangeable in Xenopus em- 
Taylor et al.

bryos and mouse fibroblasts. Development 106: 67-78.

Vaidya, T., S. Rhodes, E. Taparowsky, and S. Konieczny. 1989. Fibroblast growth factor and transforming growth factor $\beta$ repress transcription of the myogenic regulatory gene MyoD1. Mol. Cell. Biol. 9: 3576-3579.

Walsh, K. 1989. Cross-binding of factors to functionally different promoter elements in c-fos and skeletal actin genes. Mol. Cell. Biol. 9: 2191-2201.

Weintraub, H., S. Tapscott, R. Davis, M. Thayer, M. Adam, A. Lassar, and A.D. Miller. 1989. Activation of muscle-specific genes in pigment, nerve, fat, liver, and fibroblast cell lines by forced expression of MyoD. Proc. Natl. Acad. Sci. 86: 5434 5438.

Weintraub, H., R. Davis, D. Lockshon, and A. Lassar. 1990. MyoD binds cooperatively to two sites in a target enhancer sequence: Occupancy of two sites is required for activation. Proc. Natl. Acad. Sci. 87: 5623-5627.

Wilson, C., G. Cross, and H. Woodland. 1986. Tissue-specific expression of actin genes injected into Xenopus embryos. Cell 47: 589-599. 


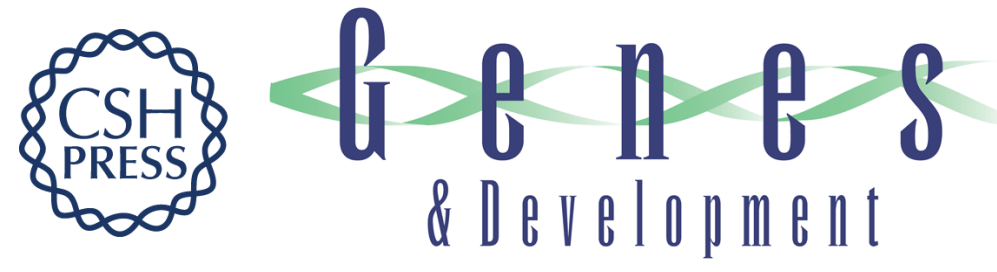

\section{Xenopus embryos contain a somite-specific, MyoD-like protein that binds to a promoter site required for muscle actin expression.}

M V Taylor, J B Gurdon, N D Hopwood, et al.

Genes Dev. 1991, 5:

Access the most recent version at doi:10.1101/gad.5.7.1149

References This article cites 42 articles, 15 of which can be accessed free at:

http://genesdev.cshlp.org/content/5/7/1149.full.html\#ref-list-1

License

Email Alerting

Service

Receive free email alerts when new articles cite this article - sign up in the box at the top right corner of the article or click here.

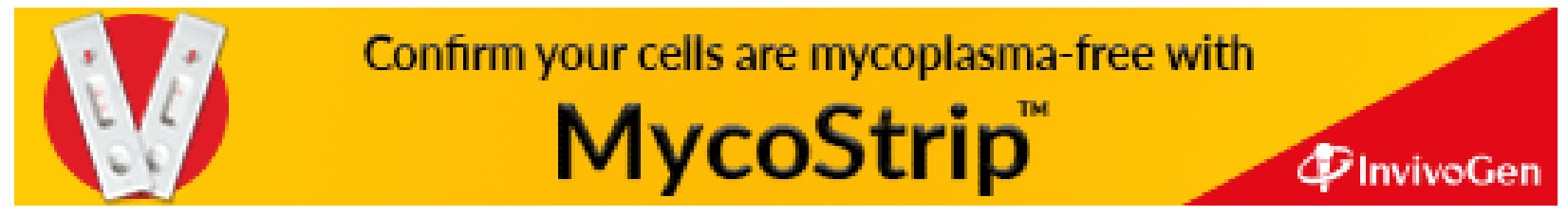

